\title{
Characterizations of $\mathrm{NdFe}_{0.5} \mathrm{Co}_{0.5} \mathrm{O}_{3}$ Trimetallic Oxide Prepared by Thermal Decomposition of Heteronuclear Complex, $\mathrm{Nd}\left[\mathrm{Fe}_{0.5} \mathrm{Co}_{0.5}(\mathrm{CN})_{6}\right] \cdot 4 \mathrm{H}_{2} \mathrm{O}$
}

\author{
Hiromichi AONO, Kouichi KINOSHITA, Masatomi SAKAMOTO* and Yoshihiko SADAOKA ${ }^{\dagger}$ \\ Department of Materials Science and Engineering, Faculty of Engineering, Ehime University, 3, Bunkyo-cho, Matsuyama-shi $790-8577$ \\ *Department of Material and Biological Chemistry, Faculty of Science, Yamagata University, \\ 1-4-12, Kojirakawa-machi, Yamagata-shi 990-8560
}

\author{
多核錯体 $\mathrm{Nd}\left[\mathrm{Fe}_{0.5} \mathrm{Co}_{0.5}(\mathrm{CN})_{6}\right] \cdot 4 \mathrm{H}_{2} \mathrm{O}$ の熱分解により作製された \\ $\mathrm{NdFe}_{0.5} \mathrm{Co}_{0.5} \mathrm{O}_{3}$ 酸化物の性質 \\ 青野宏通・木下耕一・坂本政臣 $*$ 定岡芳彦 \\ 愛媛大学工学部機能材料工学科, 790-8577 松山市文京町 3 \\ *山形大学理学部物質生命化学科, 990-8560 山形市小白川町 1-4-12
}

\begin{abstract}
$\mathrm{NdFe}_{0.5} \mathrm{Co}_{0.5} \mathrm{O}_{3}$, a trimetallic perovskite-type oxide, was prepared by thermal decomposition of a synthesized heteronuclear complex of $\mathrm{Nd}\left[\mathrm{Fe}_{0.5} \mathrm{Co}_{0.5}(\mathrm{CN})_{6}\right] \cdot 4 \mathrm{H}_{2} \mathrm{O}$. Using XRD, the perovskite-type phase was detected in the sample heated at $500^{\circ} \mathrm{C}$ and the complex was completely decomposed to $\mathrm{NdFe} \mathrm{e}_{0.5} \mathrm{Co}_{0.5} \mathrm{O}_{3}$ at $700^{\circ} \mathrm{C}$. Distribution of the elements $\mathrm{Nd}, \mathrm{Fe}$, and $\mathrm{Co}$ on the surface of the complex that decomposed at $800^{\circ} \mathrm{C}$ were homogeneous according to Auger electron spectroscopy (AES) analysis. For a solid-state reaction method using a mixture of single oxides $\left(\mathrm{Nd}_{2} \mathrm{O}_{3}, \mathrm{Fe}_{2} \mathrm{O}_{3}\right.$ and $\left.\mathrm{CoO}\right)$, a high heating temperature $\left(>1000^{\circ} \mathrm{C}\right)$ is needed to form a single phase of the perovskite-type oxide. Fe-rich and Co-rich regions on the surface were clearly detected even in a mixture calcined at $1100^{\circ} \mathrm{C}$. Surface concentration and structure of samples obtained by both methods were investigated by X-ray photoelectron spectroscopy (XPS). For both samples, XPS revealed that the $(\mathbf{F e}+\mathbf{C o}) / \mathrm{Nd}$ ratio was less than unity. [Received June 10, 1998; Accepted August 10, 1998]
\end{abstract}

Key-words : Perovskite-type oxides, $\mathrm{NdFe}_{0.5} \mathrm{Co}_{0.5} \mathrm{O}_{3}, \mathrm{XRD}, \mathrm{XPS}, \mathrm{AES}$

1. Introduction

The perovskite-type heterometallic oxides have investigated for their functional electrical properties and used in many applications such as catalysts, ${ }^{1)}$ fuel cells ${ }^{2}$ and gas sensors. ${ }^{3)-7)}$ The preparation of powders with controlled stoichiometry and microstructure is needed to achieve these applications. The conventional method of heterometallic oxide production involves a solid-state reaction of single oxides. However, this method, which uses a high sintering temperature, has several problems such as crystal growth and ease of formation of a second phase. Moreover, it is difficult to control the quality of powders used in the solid-state reaction.

In general, chemical processing methods can be conducted at lower temperature than the solid-state reaction and improve the homogeneity and reproducibility of ceramic products. ${ }^{8)}$ The preparation of $\mathrm{LnTO}_{3}$ ( $\mathrm{Ln}=$ lanthanides, $\mathrm{T}=\mathrm{Fe}$ or $\mathrm{Co}$ ) by thermal decomposition of the appropriate hexacyano complexes $\operatorname{Ln}\left[\mathrm{T}(\mathrm{CN})_{6}\right] \cdot n \mathrm{H}_{2} \mathrm{O}$ was first proposed by Gallagher in 1968. ${ }^{9}$ ) This method is very useful for obtaining homogeneous perovskite-type oxides at low temperatures. The formation of the perovskite oxide depends only on the decomposition process at low temperature, and the solid diffusion process at high temperature is not necessary, because the complexes as precursors possess the desired stoichiometry of the rare-earth ferri- or cobaltcyanides in a single compound. In previous papers, we confirmed that pure and homogeneous $\mathrm{LnTO}_{3}$ powders with relatively high specific surface areas can be synthesized by thermal decomposition of some heteronuclear complexes at low temperatures. ${ }^{10)-13)}$ Moreover, we demonstrated that it is possible to prepare a single phase of trimetallic oxides using trimetallic complexes. ${ }^{14)-18)}$ However, the homogeneity of the oxides prepared from thermal decomposition of

\footnotetext{
$\dagger$ To whom correspondence should be addressed.
}

trimetallic heteronuclear complexes has been mainly determined by X-ray diffraction (XRD) and scanning electron microscopy (SEM).

In this study, we prepared $\mathrm{NdFe}_{0.5} \mathrm{Co}_{0.5} \mathrm{O}_{3}$, trimetallic oxide, by thermal decomposition of $\mathrm{Nd}\left[\mathrm{Fe}_{0.5} \mathrm{Co}_{0.5}(\mathrm{CN})_{6}\right]$. $4 \mathrm{H}_{2} \mathrm{O}$ and the surface structures of the trimetallic oxide were mainly examined by scanning Auger spectroscopy and X-ray photoelectron spectroscopy.

\section{Experimental}

2.1 Sample preparation

2.1.1 Preparation of complexes

For the preparation of $\mathrm{Nd}\left[\mathrm{Fe}(\mathrm{CN})_{6}\right] \cdot 4 \mathrm{H}_{2} \mathrm{O}$ and $\mathrm{Nd}\left[\mathrm{Co}(\mathrm{CN})_{6}\right] \cdot 4 \mathrm{H}_{2} \mathrm{O}$, an aqueous solution $(50 \mathrm{ml})$ of hydrated lanthanide (III) nitrate $(50 \mathrm{mmol})$ was added to an aqueous solution $(55 \mathrm{ml})$ of $\mathrm{K}_{3}\left[\mathrm{Fe}(\mathrm{CN})_{6}\right](50 \mathrm{mmol})$ or $\mathrm{K}_{3}\left[\mathrm{Co}(\mathrm{CN})_{6}\right](50 \mathrm{mmol})$. The mixture was stirred at room temperature for $0.5 \mathrm{~h}$. The crystals obtained were collected by suction filtration, washed with water, ethanol and diethyl ether, and then dried in air at $50^{\circ} \mathrm{C} . \mathrm{Nd}\left[\mathrm{Fe}_{0.5} \mathrm{Co}_{0.5}\right.$ $\left.(\mathrm{CN})_{6}\right] \cdot 4 \mathrm{H}_{2} \mathrm{O}$ was synthesized by mixing equivalent amounts of lanthanum (III) nitrate hydrate and a mixture of potassium hexacyanoferrate (III) and potassium hexacyano cobaltate (III) by stirring in water $\left(0.5 \mathrm{~mol} \cdot \mathrm{dm}^{-3}\right.$ solution).

2.1.2 Preparation of $\mathrm{NdFe}_{0.5} \mathrm{Co}_{0.5} \mathrm{O}_{3}$

Two methods were employed to prepare $\mathrm{NdFe}_{0.5} \mathrm{Co}_{0.5} \mathrm{O}_{3}$. In the thermal decomposition method, $\mathrm{Nd}\left[\mathrm{Fe}_{0.5} \mathrm{Co}_{0.5}\right.$ $\left.(\mathrm{CN})_{6}\right] \cdot 4 \mathrm{H}_{2} \mathrm{O}$ was decomposed at various temperatures for $0.5 \mathrm{~h}$ in air. In the solid-state reaction method, $\mathrm{Nd}_{2} \mathrm{O}_{3}$ (99.9\%), $\mathrm{Fe}_{2} \mathrm{O}_{3}(99.99 \%)$ and $\mathrm{CoO}(>99.9 \%)$ were used as starting materials. These oxides were ball-milled for 100 $\mathrm{h}$, and then the mixture was heated for $0.5 \mathrm{~h}$ in air.

\subsection{Measurements}

The thermal decomposition process of the complexes was examined by X-ray diffraction $(\mathrm{Cu} \mathrm{K} \alpha)$ analysis and 
thermogravimetric analysis. X-ray powder diffraction analysis was conducted using Rint 2000 from Rigaku Corporation. The surface structures were characterized by Xray photoelectron spectroscopy (XPS) using Perkin-Elmer XPS1600E $(\mathrm{Mg} \mathrm{K} \alpha)$, and the elemental distributions by Auger electron spectroscopy (AES) using Perkin-Elmer $\phi$ $650 \mathrm{E}$. All binding energies for XPS were referred to the $\mathrm{C} 1 \mathrm{~s}$ photoemission line spectrum at $284.5 \mathrm{eV}$. For measurements, the sample powder was pressed into a pellet at a pressure of $1 \times 10^{8} \mathrm{~Pa}$ and was heated at $500^{\circ} \mathrm{C}$ in air and transferred to a high-vacuum chamber $\left(<3 \times 10^{-7} \mathrm{~Pa}\right)$.

\section{Results and discussion}

\subsection{Thermal analysis}

Figure 1 shows the TGA (thermogravimetric analysis) curves for the complexes of $\mathrm{Nd}\left[\mathrm{Fe}(\mathrm{CN})_{6}\right] \cdot 4 \mathrm{H}_{2} \mathrm{O}(\mathrm{NdFe}$ complex), $\mathrm{Nd}\left[\mathrm{Fe}_{0.5} \mathrm{Co}_{0.5}(\mathrm{CN})_{6}\right] \cdot 4 \mathrm{H}_{2} \mathrm{O}\left(\mathrm{NdFe}_{0.5} \mathrm{Co}_{0.5}\right.$ complex), and $\mathrm{Nd}\left[\mathrm{Co}(\mathrm{CN})_{6}\right] \cdot 4 \mathrm{H}_{2} \mathrm{O}$ ( $\mathrm{NdCo}$ complex). The dehydration of the complexes begins at about $100^{\circ} \mathrm{C}$, and a plateau is observed around $300^{\circ} \mathrm{C}$. The weight loss percentage at $280^{\circ} \mathrm{C}$ agrees with the value calculated by assuming the dehydration of four water molecules. The weight loss due to exothermic decomposition of the cyanide group begins at around $350^{\circ} \mathrm{C}$, and gradual decreases are observed up to $680^{\circ} \mathrm{C}$, followed by a final plateau. The weight loss percentage in the last plateau range agrees very well with that calculated by assuming the formation of $\mathrm{NdFe}_{x} \mathrm{Co}_{1-x} \mathrm{O}_{3}$. The starting temperature for $\mathrm{CN}$ decomposition of the complexes follows the order $\mathrm{NdCo}$ complex $>\mathrm{NdFe}_{0.5} \mathrm{Co}_{0.5} \mathrm{com}$ plex $>\mathrm{NdFe}$ complex.

IR spectra of the samples were also examined to clarify the decomposition process. IR band assigned to carbonate groups was observed for the complexes heated at $400^{\circ} \mathrm{C}$ in air. The carbonates gradually decomposed with increasing calcining temperature for all the complexes. For complexes that decomposed above $700^{\circ} \mathrm{C}$, such IR bands were no longer observed, and only strong broad bands around 600 $\mathrm{cm}^{-1}$ assigned to the oxide appeared. The complexes were completely decomposed to oxides above $700^{\circ} \mathrm{C}$.

\subsection{XRD results}

Figure 2 shows XRD results for samples heated at $900^{\circ} \mathrm{C}$ for $0.5 \mathrm{~h}$ in air. The perovskite oxides $\mathrm{NdFe}_{x} \mathrm{Co}_{1-x} \mathrm{O}_{3}$ were obtained by heating the $\mathrm{NdFe}_{x} \mathrm{Co}_{1-x}$ complexes. The XRD results for the samples obtained by thermal decomposition showed that the crystal had an orthorhombic perovskitetype structure. The peaks were shifted to lower $2 \theta$ with an increase in $\mathrm{Fe}$ content, since $\mathrm{Fe}^{3+}$ ion has a larger radius than $\mathrm{Co}^{3+}$ ion. For the obtained $\mathrm{NdFe}_{x} \mathrm{Co}_{1-x} \mathrm{O}_{3}$ system, the

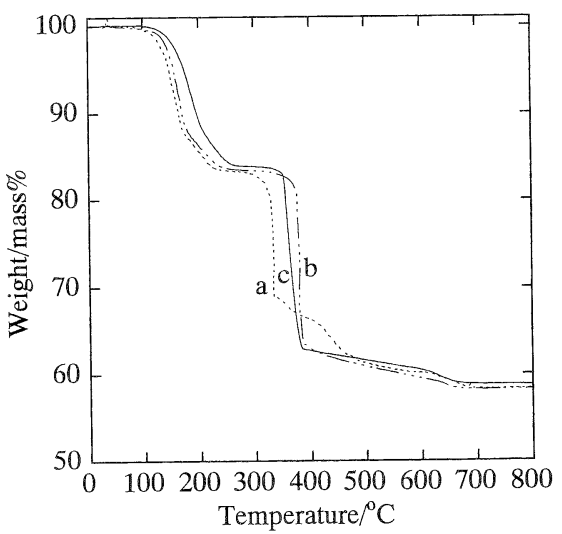

Fig. 1. TGA curves of the complexes in air. Heating rate is $5^{\circ} \mathrm{C} / \mathrm{min}$.

(a) NdFe complex, (b) $\mathrm{NdCo}$ complex, (c) $\mathrm{Nd}_{0.5} \mathrm{Fe}_{0.5} \mathrm{Co}$ complex.

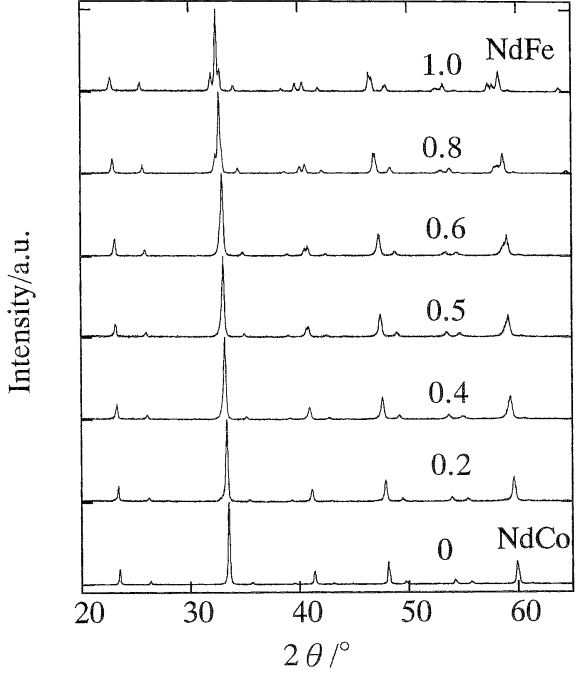

Fig. 2. XRD results for $\mathrm{Nd}_{x} \mathrm{Fe}_{1-x} \mathrm{Co}$ complexes at $900^{\circ} \mathrm{C}$. The values of $x$ are shown in the figure.

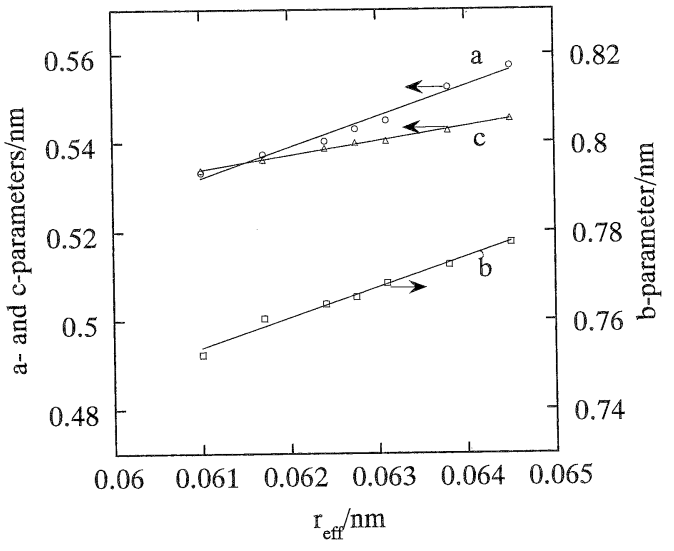

Fig. 3. Correlation between lattice parameters and $r_{\text {eff. }}$.

correlation between the lattice parameters as a space group $P n c m$ and the ionic radius (coordination number $=6$ ) of $\mathrm{T}^{3+}$ is shown in Fig. 3. In this figure, we use the effective ionic radius parameter of $\mathrm{T}^{3+}$ ions in the oxides, which is defined by $r_{\text {eff }}=x r_{\mathrm{Fe}}+(1-x) r_{\mathrm{Co}}$. This parameter takes into account the effective size of $\mathrm{T}^{3+}$ ions present in each oxide. ${ }^{18)}$ A linear relationship between the lattice parameters and $r_{\text {eff }}$ is observed for all axes. From these results, $\mathrm{Fe}^{3+}$ and $\mathrm{Co}^{3+}$ ions homogeneously occupy to $\mathrm{T}^{3+}$ ion sites of the perovskite $\mathrm{LnTO}_{3}$ material obtained by thermal decomposition of the trimetallic complex.

Figures 4 presents XRD results for the $\mathrm{NdFe}_{0.5} \mathrm{Co}_{0.5}$ complex decomposed at various temperatures. The $\mathrm{NdFe}_{0.5}$ $\mathrm{Co}_{0.5}$ complex decomposed at $500^{\circ} \mathrm{C}$ consists of the perovskite-type oxide and contains no $\mathrm{X}$-ray detectable impurities such as $\mathrm{Nd}_{2} \mathrm{O}_{3}, \mathrm{Fe}_{2} \mathrm{O}_{3}, \mathrm{CoO}$ and $\mathrm{Co}_{2} \mathrm{O}_{3}$. Furthermore, it is confirmed that the full-width-at-half-maximum (FWHM) of all the peaks for the orthorhombic phase decreases with an increase in decomposition temperature.

When a mixture of $\mathrm{NdFe}$ and $\mathrm{NdCo}$ complexes was used for preparation of the trimetallic oxide, no single phase could be obtained without a mixing process. In the case of a $1: 1$ mixture of the two complexes prepared by mixing in a mortar and pestle, separated $\mathrm{NdFeO}_{3}$ and $\mathrm{NdCoO}_{3}$ phases were detected by XRD when the mixture was decomposed at $1000^{\circ} \mathrm{C}$ and the formation of a single phase of $\mathrm{NdFe}_{0.5}$ 


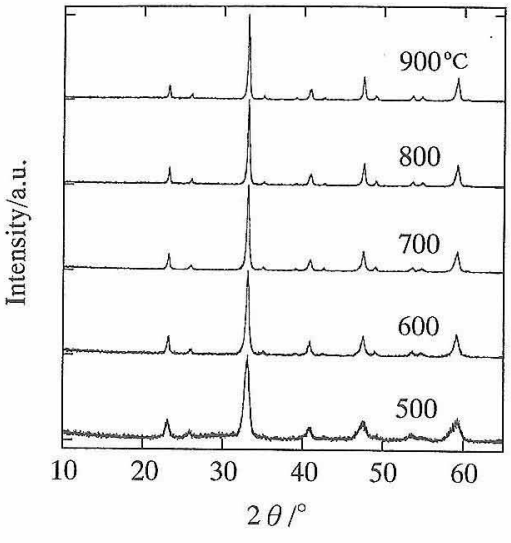

Fig. 4. XRD results for the decomposed $\mathrm{Nd}_{x} \mathrm{Fe}_{1-x} \mathrm{Co}$ complexes. Decomposition temperatures are shown in the figure.

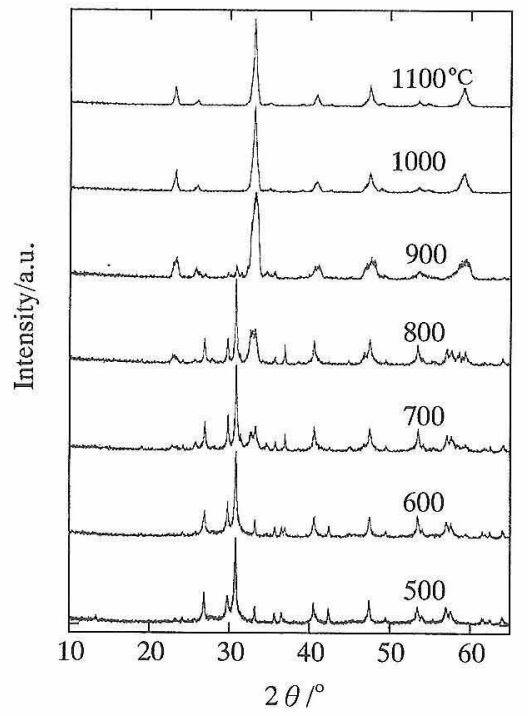

Fig. 5. XRD results for the calcined mixture of $\mathrm{Nd}_{2} \mathrm{O}_{3}, \mathrm{Fe}_{2} \mathrm{O}_{3}$ and $\mathrm{CoO}$ after ball-milling for $100 \mathrm{~h}$. Calcining temperatures are shown in the figure.

$\mathrm{Co}_{0.5} \mathrm{O}_{3}$ was not observed because the mixing in the mortar and pestle is incomplete. We could obtain a single phase of $\mathrm{NdFe}_{0.5} \mathrm{Co}_{0.5} \mathrm{O}_{3}$ at low temperatures only when the mixture was thoroughly ball-milled for $100 \mathrm{~h}$.

In the case of the solid-state reaction method, a $1: 0.5: 1$ mixture of $\mathrm{Nd}_{2} \mathrm{O}_{3}, \mathrm{Fe}_{2} \mathrm{O}_{3}$ and $\mathrm{CoO}$ was used to synthesize the $\mathrm{NdFe}_{0.5} \mathrm{Co}_{0.5} \mathrm{O}_{3}$ phase. In this method, the starting materials were heated after ball-milling for $100 \mathrm{~h}$. Figure 5 shows XRD results for the mixture of single oxides. In the case of the mixed oxide samples, a high sintering temperature of $1000^{\circ} \mathrm{C}$ was needed to obtain the perovskitetype single phase. Mixed phases containing starting single oxides were observed in the mixtures calcined at temperatures lower than $1000^{\circ} \mathrm{C}$.

\subsection{Surface analysis}

As is well known, the perovskite-type oxides have been investigated for their functional electrical properties and used in many applications such as catalysts and gas sensors. It seems that the catalytic activity and the sensing characteristics are strongly influenced by the surface structure. To characterize the surface structure, AES and XPS were conducted.

Figure 6 shows the SEM-Auger results for the $\mathrm{NdFe}_{0.5}$ $\mathrm{Co}_{0.5}$ complex decomposed at $800^{\circ} \mathrm{C}$. It was confirmed by

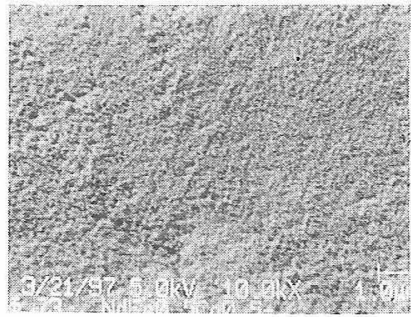

SEM

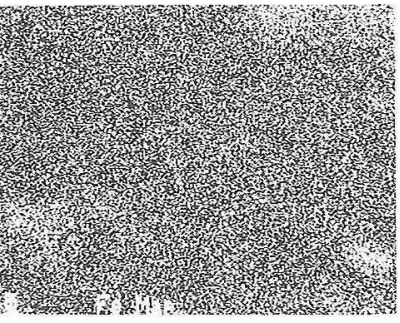

$\mathrm{Fe}$

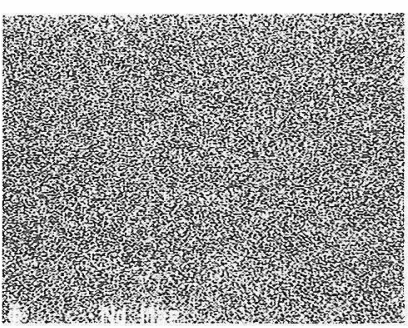

Nd

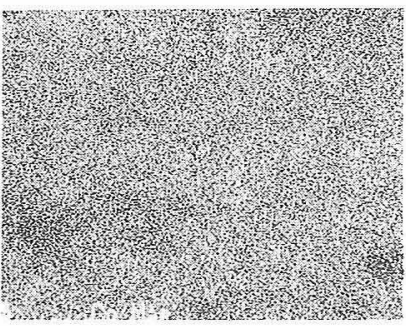

$\mathrm{Co}$
Fig. 6. SEM-Auger results for the $\mathrm{NdFe}_{0.5} \mathrm{CO}_{0.5}$ complex which decomposed at $800^{\circ} \mathrm{C}$.

SEM observation that particle size was smaller than 200 $\mathrm{nm}$. The elemental distribution of $\mathrm{Nd}, \mathrm{Fe}$ and $\mathrm{Co}$ is highly homogeneous. Figures 7 and 8 show the elemental maps of the surface for the mixture of single oxides calcined at 800 and $1100^{\circ} \mathrm{C}$, respectively. For the mixture calcined at $800^{\circ} \mathrm{C}, \mathrm{Fe}$ - and Nd-rich phases were clearly separated from the Co-rich phase because this mixture consists of the perovskite-type phase and the single oxides (see Fig. 5). A more homogeneous distribution of $\mathrm{Nd}, \mathrm{Fe}$ and $\mathrm{Co}$ was observed for the single oxide mixture calcined at $1100^{\circ} \mathrm{C}$. XRD results confirmed the formation of a single phase of the perovskite-type $\mathrm{NdFe}_{0.5} \mathrm{Co}_{0.5} \mathrm{O}_{3}$ for the complex which decomposed at $700^{\circ} \mathrm{C}$ and for the mixture calcined at temperatures above $1000^{\circ} \mathrm{C}$. However, the homogeneity of the solid-state reaction sample at $1100^{\circ} \mathrm{C}$ was clearly poorer than that of the $\mathrm{NdFe} e_{0.5} \mathrm{Co}_{0.5}$ complex which decomposed at $800^{\circ} \mathrm{C}$

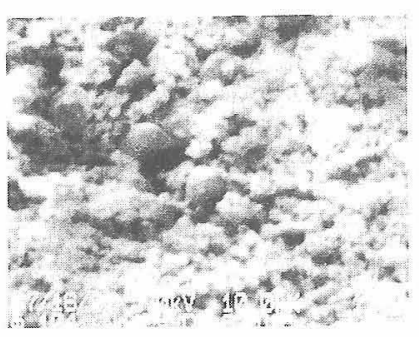

SEM $2 \mu \mathrm{m}$

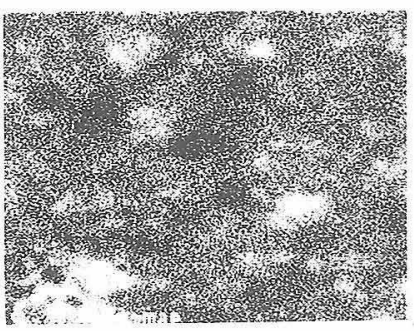

$\mathrm{Fe}$

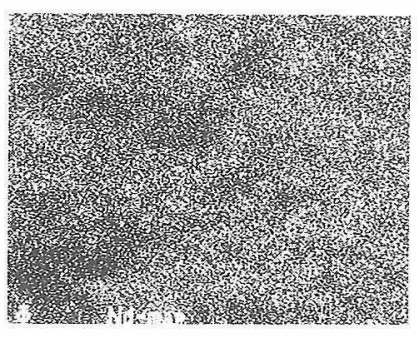

$\mathrm{Nd}$

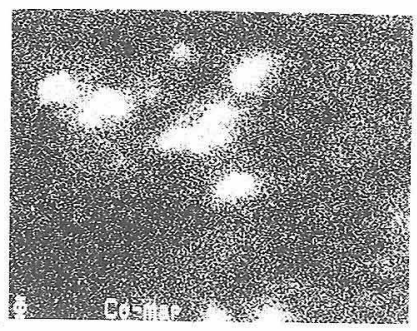

Co
Fig. 7. SEM-Auger results for the mixture of single oxides which calcined at $800^{\circ} \mathrm{C}$. 


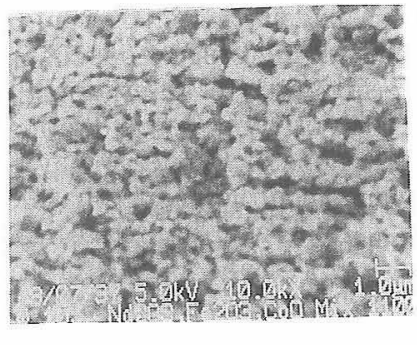

SEM $\quad 2 \mu \mathrm{m}$

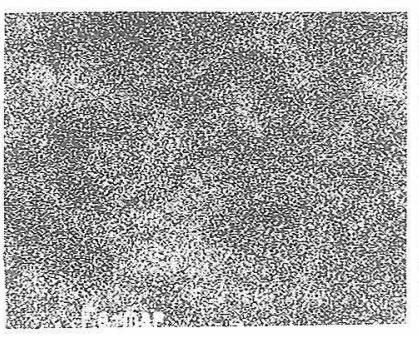

$\mathrm{Fe}$

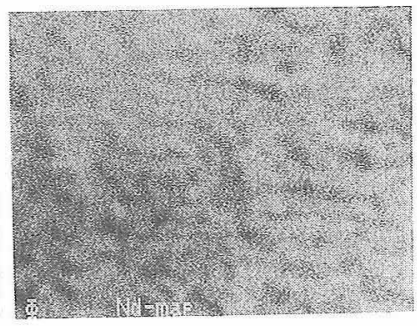

$\mathrm{Nd}$

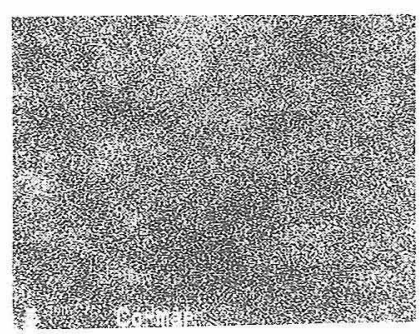

Co
Fig. 8. SEM-Auger results for the mixture of single oxides which calcined at $1100^{\circ} \mathrm{C}$.

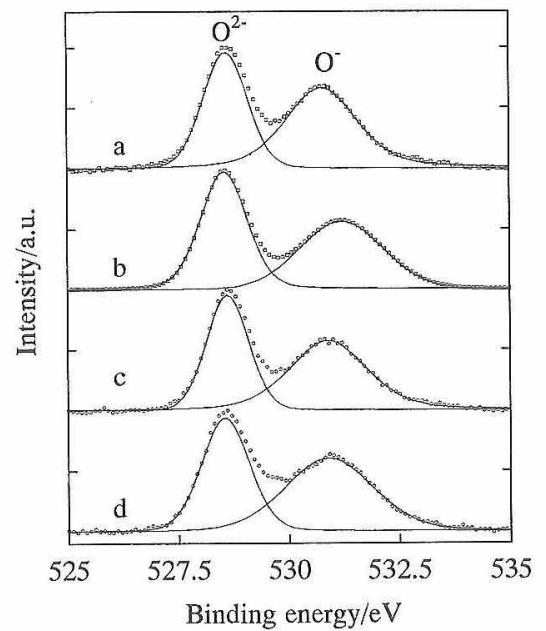

Fig. 9. XPS spectra of $\mathrm{O} 1 \mathrm{~s}$ of the samples heated at $1000^{\circ} \mathrm{C}$ for $0.5 \mathrm{~h}$. The step size for the measurement is $0.10 \mathrm{eV}$.

(a) $\mathrm{NdFe}$ complex, (b) $\mathrm{NdCo}$ complex, (c) $\mathrm{NdFe}_{0.5} \mathrm{Co}_{0.5}$ complex, (d) mixture of single oxides.

B.E. and FWHM values are shown in the Table 1.

Figure 9 shows the XPS results for oxygen (O1s) on the surface of various samples heated at $1000^{\circ} \mathrm{C}$ in air. In the case of samples heated at $1000^{\circ} \mathrm{C}$, the $\mathrm{XRD}$ results indicated the formation of the perovskite-type single phase for all the samples examined. Two peaks of O (low B.E.) and $O$ (high B.E.) are ascribed to lattice oxygen $\left(\mathrm{O}^{2-}\right)$ of the perovskite-type structure and adsorbed oxygen $\left(\mathrm{O}^{-}\right)$ on the particle surface, respectively. The binding energy (B. E.) and FWHM are summarized in Table 1. For the lattice oxygen, B.E. values were very similar, ranging from 528.56 to $528.59 \mathrm{eV}$ for all the samples examined. However, FWHM for the decomposed $\mathrm{NdFe}_{0.5} \mathrm{Co}_{0.5} \mathrm{com}-$ plex (c) is smaller than that for the heated mixture (d). On the other hand, for the adsorbed oxygen, B. E. followed the order of decomposed NdCo complex $>$ heated mixture $>$ decomposed $\mathrm{NdFe}_{0.5} \mathrm{Co}_{0.5}$ complex $>$ decomposed $\mathrm{NdFe}$ complex. B.E. for the decomposed $\mathrm{NdFe}_{0.5} \mathrm{CO}_{0.5}$ complex (c) was slightly lower than that for the mixture (d) and
Table 1. Binding Energy and FWHM of O1s Electrons for the Oxides Shown in Fig. 9

\begin{tabular}{|c|c|c|c|c|c|}
\hline \multirow[b]{2}{*}{ sample } & \multirow[b]{2}{*}{$\begin{array}{l}\text { eat treatment } \\
\text { emperature }\end{array}$} & \multicolumn{2}{|c|}{$\mathrm{O}^{2-}$ (lattice) } & \multicolumn{2}{|c|}{$\mathrm{O}^{-}$(adsorbed) } \\
\hline & & B.E. & FWHM & B.E. & FWHM \\
\hline & & & & & \\
\hline (a) $\mathrm{NdFeO}_{3}$ & 1000 & 528.59 & 1.18 & 530.77 & 1.92 \\
\hline (b) $\mathrm{NdCoO}_{3}$ & 1000 & 528.56 & 1.23 & 531.21 & 2.20 \\
\hline (c) $\mathrm{NdFe}_{0.5} \mathrm{Co}_{0.5} \mathrm{O}_{3}$ & 1000 & 528.59 & 1.12 & 530.89 & 2.06 \\
\hline (d) mixture & 1000 & 528.56 & 1.28 & 530.95 & 2.35 \\
\hline
\end{tabular}

Table 2. Surface Atomic Ratios for the Oxides Shown in Fig. 9

\begin{tabular}{lccccccc}
\hline sample & $\begin{array}{c}\text { heat treatment } \\
\text { temperature }\end{array}$ & $\mathrm{Fe} / \mathrm{Nd}$ & $\mathrm{Co} / \mathrm{Nd}$ & $\frac{\mathrm{O}_{\text {total }}}{(\mathrm{Nd}+\mathrm{Fc}+\mathrm{Co})}$ & $\frac{\mathrm{O}^{2-}}{(\mathrm{Nd}+\mathrm{Fe}+\mathrm{Co})}$ & $\frac{\mathrm{O}^{-}}{\mathrm{O}^{2-}}$ \\
\hline (a) $\mathrm{NdFeO}_{3}$ & 1000 & 0.310 & 0.000 & 1.63 & 0.72 & 1.27 \\
(b) $\mathrm{NdCoO}_{3}$ & 1000 & 0.000 & 0.269 & 1.54 & 0.79 & 0.96 \\
(c) $\mathrm{NdFe}_{0.5} \mathrm{Co}_{0.5} \mathrm{O}_{3}$ & 1000 & 0.141 & 0.140 & 1.56 & 0.70 & 1.24 \\
(d) $\mathrm{mixture}^{10}$ & 1000 & 0.157 & 0.126 & 1.46 & 0.66 & 1.20 \\
\hline
\end{tabular}

these values are located between those for the decomposed $\mathrm{NdFe}$ complex and the NdCo complex. The FWHM for the decomposed complex also is smaller than that for the mixture (d). These results mean that the surface structure of the complex is more homogeneous than that of the mixture. Some oxides might remain on the surface of the sample obtained by the solid state reaction method (d).

The surface atomic ratios are summarized in Table 2. While the ratio of $\mathrm{O}_{\text {(total) }} /(\mathrm{Nd}+\mathrm{Fe}+\mathrm{Co})$ was about 1.5 for all the samples, the ratio of $\mathrm{O}_{\text {(lattice) }} /(\mathrm{Nd}+\mathrm{Fe}+\mathrm{Co})$ was apparently lower than 1.5 for the stoichiometric compounds. The oxidative nonstoichiometry for $\mathrm{LaFeO}_{3}$ and reductive nonstoichiometry for $\mathrm{LaCoO}_{3}$ were reported by Fierro and Tejuca. ${ }^{19)}$ In the examined samples, the C1s of carbonates was detected, which suggests that $\mathrm{CO}$ and $\mathrm{CO}_{2}$ adsorb on the oxidized surface of the perovskite-type oxides and the carbonates preferentially form with lattice $\mathrm{O}^{2-}$ ions as the yielding of the carbonate. It is well known that the binding energy of $\mathrm{O} 1 \mathrm{~s}$ of the carbonates is similar to that of $\mathrm{O}^{-}$. Xi et al. reported that for $\mathrm{LaFeO}_{3}$, the ratio of the chemisorbed oxygen and the lattice oxygen of nanosize crystals increases with a decrease in the mean crystal size and the signal of the chemisorbed oxygen is less intense than that of the lattice oxygen when the average crystal size is larger than $15 \mathrm{~nm} .{ }^{20)}$ For the complex which decomposed at $1000^{\circ} \mathrm{C}$, the $\mathrm{O}^{-} / \mathrm{O}^{2-}$ ratio was 1.24 . It is considered that the $\mathrm{O}^{-} / \mathrm{O}^{2-}$ ratio is also influenced by the crystal size. To clarify the effect of particle sizes, samples having different particle size were prepared using $\alpha$-terpineol as an additive for particle growth. Actually, for $\mathrm{NdFeO}_{3}$ powders shown in Fig. 10, the ratio was 1.49 for sample (a) and 1.02 for sample (b).

The XPS spectra of the Co2p level of the decomposed $\mathrm{NdFe}_{0.5} \mathrm{Co}_{0.5}$ complex and the mixture calcined at $1000^{\circ} \mathrm{C}$ were examined and the spin-orbit splitting between $2 \mathrm{p}_{3 / 2}$ and $2 \mathrm{p}_{1 / 2}$ peaks was found to be $15.22 \mathrm{eV}$ for both samples; therefore, the oxidation state of cobalt may be attributed to $\mathrm{Co}^{3+}$ in the samples. Figure 11 shows the XPS results for Co $2 p_{3 / 2}$. In the range of $776-790 \mathrm{eV}$, two overlapping peaks were commonly observed. For the peak appearing at a lower binding energy, the binding energy and FWHM were 779.54 and $1.58 \mathrm{eV}$, respectively, for the $\mathrm{NdFe}_{0.5} \mathrm{Co}_{0.5}$ 


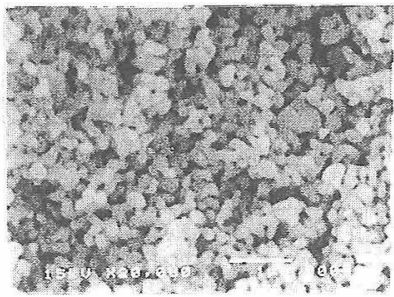

a

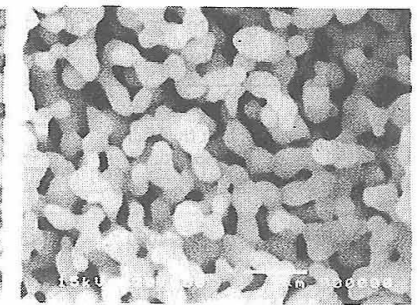

$\mathrm{b}$
$2 \mu \mathrm{m}$

Fig. 10. SEM-micrographs of the two types of decomposed $\mathrm{NdFe}$ complexes at $1000^{\circ} \mathrm{C}$.

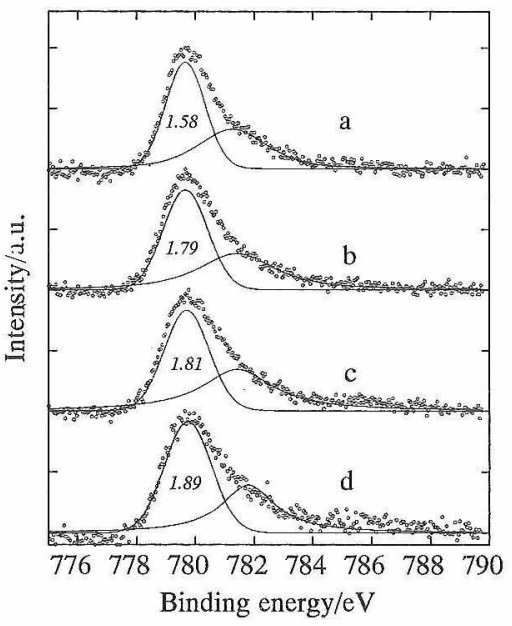

Fig. 11. XPS spectra of Co $2 \mathrm{p}_{3 / 2}$ of the samples. The step size for the measurement is $0.05 \mathrm{eV}$.

(a) $\mathrm{NdFe}_{0.5} \mathrm{Co}_{0.5}$ complex which decomposed at $1000^{\circ} \mathrm{C}$, (b) mixture of single oxides which calcined at $1000^{\circ} \mathrm{C}$, (c) mixture of single oxides which calcined at $900^{\circ} \mathrm{C}$, (d) mixture of single oxides which calcined at $800^{\circ} \mathrm{C}$.

FWHM values are shown in the figure.

complex decomposed at $1000^{\circ} \mathrm{C}$. In the case of the mixture, the binding energy and FWHM were influenced by the calcining temperature, i.e., they were $779.72 \mathrm{eV}$ and 2.49 $\mathrm{eV}\left(700^{\circ} \mathrm{C}\right), 779.70 \mathrm{eV}$ and $1.89 \mathrm{eV}\left(800^{\circ} \mathrm{C}\right), 779.70 \mathrm{eV}$ and $1.81 \mathrm{eV}\left(900^{\circ} \mathrm{C}\right)$, and $779.61 \mathrm{eV}$ and $1.79 \mathrm{eV}\left(1000^{\circ} \mathrm{C}\right)$, respectively. Lombardo et al. reported that for $\mathrm{LaCoO}_{3}$, the binding energies $\left(2 \mathrm{p}_{3 / 2}\right)$ of $\mathrm{Co}^{0}, \mathrm{Co}^{3+}$ and $\mathrm{Co}^{2+}$ are 778.0 $\mathrm{eV}, 779.6$ and $780.3 \mathrm{eV}$, respectively. ${ }^{21}$ The binding energies ( $\mathrm{Co} 2 \mathrm{p}_{3 / 2}$ ) of $\mathrm{CoO}, \mathrm{Co}_{3} \mathrm{O}_{4}$ and $\mathrm{Co}_{2} \mathrm{O}_{3}$ are 780.4 , 780.2 and $779.9 \mathrm{eV}$, respectively. ${ }^{22)}$ The decrease of FWHM of Co $2 \mathrm{p}_{3 / 2}$ with an increase in calcining temperature may result from a decrease in the amount of $\mathrm{CoO}$ and $\mathrm{Co}_{3} \mathrm{O}_{4}$ on the surface. The observed changes in $\mathrm{B}$. $\mathrm{E}$. and FWHM with the calcining temperature confirmed the disappearance of the Co-rich region with increasing temperature as observed by Auger spectroscopy (Figs. 7 and 8). The binding energy of the second (shoulder) peak appearing at a higher binding energy was 781.3-781.8 eV. It seems that the peak position shifted to a lower binding energy with an increase in the calcining temperature of the mixture $\left(781.8 \mathrm{eV}\right.$ for the mixture calcined at $\left.800^{\circ} \mathrm{C}\right)$. From our experimental results $(781.5 \mathrm{eV})$, this peak was assigned to $\mathrm{CoCO}_{3}$, since $\mathrm{Cl}$ s of carbonates was also observed in the 288.5-289.1 eV region.

For the $\mathrm{NdFe}_{0.5} \mathrm{Co}_{0.5}$ complex decomposed at $1000^{\circ} \mathrm{C}$, the $(\mathrm{Fe}+\mathrm{Co}) / \mathrm{Nd}$ ratio was lower than unity. Similar results were also observed for the other oxides examined. While it must be considered the effects of heterogeneous depth distribution and elastic scattering, etc. to determine the ratio exactly, it seems that the ratio of $(\mathrm{Fe}+\mathrm{Co}) / \mathrm{Nd}$ ratio is less than unity and the observed nonstoichiometry may be limited only to the surface layer, since the single phase of the perovskite-type oxide was observed by XRD. The $\mathrm{Fe} / \mathrm{Nd}$ and $\mathrm{Co} / \mathrm{Nd}$ ratios were 0.141 and 0.140 for the $\mathrm{NaFe}_{0.5} \mathrm{Co}_{0.5}$ complex decomposed at $1000^{\circ} \mathrm{C}$ and 0.157 and 0.126 for the mixture calcined at $1000^{\circ} \mathrm{C}$, respectively. Furthermore, for $\mathrm{NdFe}$ and $\mathrm{NdCo}$ complexes decomposed at $1000^{\circ} \mathrm{C}$, the $\mathrm{Fe} / \mathrm{Nd}$ and $\mathrm{Co} / \mathrm{Nd}$ ratios were 0.310 and 0.269 , respectively. These results suggest that the $\mathrm{Nd}$-rich region was formed on the surface of the single phase of the perovskite-type oxide. According to XPS or Auger electron spectroscopy, the surface composition is usually very different from the bulk composition for most multicomponent systems. Overbury et al. reviewed various thermodynamic models for practical determination of surface composition. ${ }^{23)}$ They indicated that the surface tension of the components is important for determining the surface composition. The Gibbs free energies for $\mathrm{Nd}_{2} \mathrm{O}_{3}, \mathrm{CoO}$ and $\mathrm{FeO}$ are $-1808,-211$ and $-245 \mathrm{~kJ} / \mathrm{mol}$, respectively. Consequently, $\mathrm{Nd}_{2} \mathrm{O}_{3}$ seemed to be the first to be formed on the surface during the calcination. The Gibbs free energy values seem to explain well the order in which the ratios of surface concentration, $\mathrm{Fe} / \mathrm{Nd}, \mathrm{Co} / \mathrm{Nd}$ and $(\mathrm{Fe}+\mathrm{Co}) / \mathrm{Nd}$, were observed in this work.

\section{Conclusion}

The trimetallic oxide, $\mathrm{NdFe}_{0.5} \mathrm{Co}_{0.5} \mathrm{O}_{3}$, which was prepared by thermal decomposition of $\mathrm{NdFe}_{0.5} \mathrm{CO}_{0.5} \mathrm{com}-$ plex, consisted of a single phase of perovskite-type oxide and the elemental distributions of $\mathrm{Nd}, \mathrm{Fe}$ and $\mathrm{Co}$ on the surface showed high homogeneity while the $(\mathrm{Fe}+\mathrm{Co}) / \mathrm{Nd}$ ratio was less than unity. For the solid-state reaction method using a mixture of single oxides $\left(\mathrm{Nd}_{2} \mathrm{O}_{3}, \mathrm{Fe}_{2} \mathrm{O}_{3}\right.$ and $\mathrm{CoO})$, a high heating temperature $\left(>1000^{\circ} \mathrm{C}\right)$ was needed to form the single phase of the perovskite-type oxide. For the mixture calcined at $800^{\circ} \mathrm{C}, \mathrm{Fe}$-rich and Co-rich regions were clearly detected and no perovskite-type oxide was formed as the major product, while the perovskite-type oxide was formed at $500^{\circ} \mathrm{C}$ and higher temperature by the decomposition of $\mathrm{NdFe}_{0.5} \mathrm{Co}_{0.5}$ complex. From these results, we concluded that the thermal decomposition of a trimetallic heteronuclear complex is an excellent method for obtaining the single phase of a trimetallic perovskitetype oxide.

Acknowledgments The present work was supported by a Grant-in-Aid for Scientific Research on Priority Areas "New Development of Rare Earth Complexes" (Nos. 08220250 and 06241106) from the Ministry of Education, Science, Sports and Culture of Japan.

\section{References}

1) J. G. McCarty and H. Wise, Catalysis Today, 8, 231-48 (1990).

2) N. Q. Minh, J. Am. Ceram. Soc., 76, 563-88 (1993).

3) T. Arakawa, H. Kurachi and J. Shiokawa, J. Mater. Sci., 4, 1207-10 (1985)

4) Y. Shimizu, M. Shimabukuro, H. Arai and T. Seiyama, Chem. Lett., 1985, 917-20.

5) T. Arakawa, K. Takada, Y. Tsunemine and J. Shiokawa, Sensors and Actuators, 14, 215-21 (1988).

6) Y. Matsuura, S. Matsushima, M. Sakamoto and Y. Sadaoka, J. Mater. Chem., 3, 767-69 (1993).

7) E. Traversa, S. Matsushima, G. Okada, Y. Sadaoka, Y. Sakai and K. Watanabe, Sensors and Actuators B, 24/25, 661-64 (1995). 
8) M. Kakihana, J. Sol-Gel Sci. Technol., 6, 7-55 (1996).

9) P. K. Gallagher, Mater. Res. Bull., 3, 225-32 (1968).

10) S. Nakayama, M. Sakamoto, K. Matsuki, Y. Okimura, R. Ohsumi, Y. Nakayama and Y. Sadaoka, Chem. Lett., 1992, 2145-48.

11) Y. Sadaoka, K. Watanabe, Y. Sakai and M. Sakamoto, J. Alloys Compounds, 224, 194-98 (1995).

12) Y. Sadaoka, K. Watanabe, Y. Sakai and M. Sakamoto, J. Ceram. Soc. Japan, 103, 519-22 (1995).

13) E. Traversa, M. Sakamoto and Y. Sadaoka, J. Am. Ceram. Soc., 76, 1401-04 (1996).

14) E. Traversa, P. Nunziante, M. Sakamoto, K. Watanabe, Y. Sadaoka and Y. Sakai, Chem. Lett., 1995, 189-90.

15) Y. Sadaoka, E. Traversa and M. Sakamoto, Chem. Lett., 1996, 177-78.

16) Y. Sadaoka, E. Traversa and M. Sakamoto, J. Alloys Com- pounds, 240, 51-59 (1996).

17) Y. Sadaoka, E. Traversa and M. Sakamoto, J. Mater. Chem., 6, 1355-60 (1996)

18) M. Sakamoto, P. Nunziante, E. Traversa, S. Matsushima, M. Miwa, H. Aono and Y. Sadaoka, J. Ceram. Soc. Japan, 105, 963-69 (1997).

19) J. L. G. Fierro and L. G. Tejuca, Appl. Surf. Sci., 27, 453-57 (1987).

20) L. Xi, L. Xiaoxum, X. Baokun and Z. Muyu, J. Alloys Compounds, 186, 315-19 (1992).

21) E. A. Lombardo, K. Tanaka and I. Toyoshima, J. Catalysis, 80, 340-49 (1983).

22) "Handbook of X-ray Photoelectron Spectroscopy," Ed. by J. Chastain, Perkin-Elmer Co., Minnesota (1992) p. 219.

23) S. H. Overbury, P. A. Bertrand and G. A. Somorjai, Chem. Review, 75, 587 (1975). 